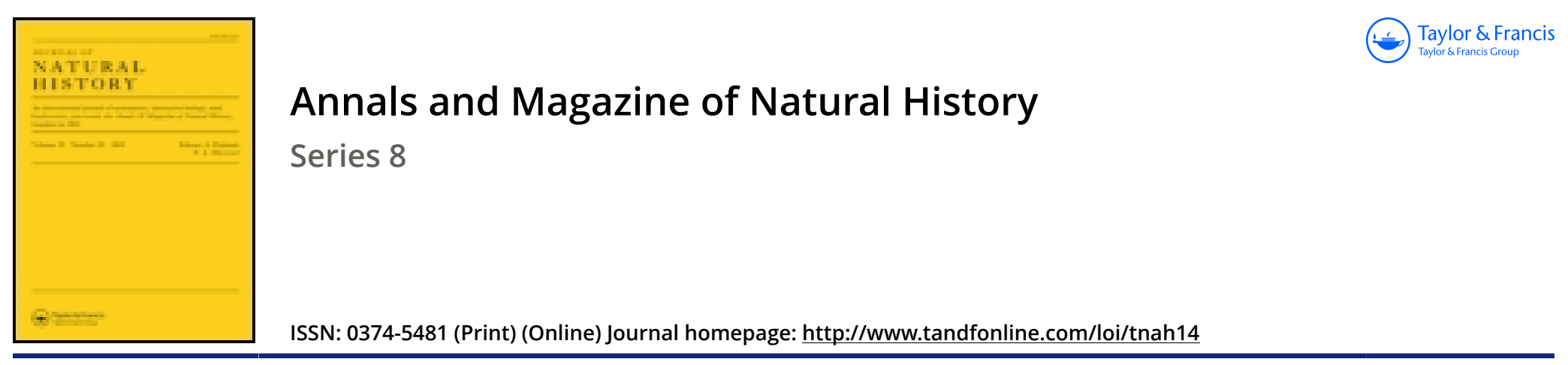

\title{
VI.-Notes on the Apidæ (Hymenoptera) in the collection of the British Museum, with descriptions of new species
}

\section{Geoffrey Meade-Waldo M.A.}

To cite this article: Geoffrey Meade-Waldo M.A. (1914) VI.-Notes on the Apidæ (Hymenoptera) in the collection of the British Museum, with descriptions of new species, Annals and Magazine of Natural History, 13:73, 45-58, DOI: 10.1080/00222931408693454

To link to this article: http://dx.doi.org/10.1080/00222931408693454

曲 Published online: 15 Sep 2009.

Submit your article to this journal $\pi$

Џll Article views: 2

Q View related articles $₫$ 
Skull. Much as in B. c. planiceros, but somewhat smaller. Orbits moderately projecting; rostrum slender; occiput broad and low.

Horns. Distinguished from those of B. c. planiceros and $B$. . beddingtoni by the palm being directed more backwards than in either of them. Palm not depending, almost erected; tips long, stout, strongly bent inwards, more so than in planiceros and beddingtoni, and backwards at the extreme end, scarcely erected at all. Greatest width of horns very small comparatively.

This well-marked buffalo has nothing to do with $B$. $c$. brachyceros of Lake Chad, with which it has been identified by Mr. Lydekker in the 'Catalogue of Ungulates.' Specimen 4. 7. 9. 13 of the British Museum belongs to this race. As a matter of fact, under the head of B. c. brachyceros a number of various races have been mixed up. On the other hand, specimens referable to B. c. brachyceros are treated as different species.

VI.-Notes on the Apida (Hymenoptera) in the Collection of the British Museum, with Descriptions of new Species. By Geoffrey Meade-Waldo, M.A.

(Published by permission of the Trustees of the British Museum.)

\section{Subfamily ANthopzorINA.}

The following paper deals solely with the genus Anthophora, Latr. Nine new species and two new varieties are described, and some notes on described species added, together with certain points on synonymy.

The types are all in the British Museum.

\section{Anthophora, Latr.}

Key to the new Species here described.

1. (2) First recurrent nervure in fore wing received at apex of second cubital cell, interstitial with second transverse cubital nervure (subg. Habropoda) $\ldots \ldots \ldots \ldots \ldots \ldots \ldots \ldots$

2. (1) First recurrent nervure received at rowlandi, sp. $\mathbf{n}$.

$[($ Assam.) middle of second cubital cell.

3. (4) Pubescence of abdomen emerald-green. Length $16 \mathrm{~mm}$.

hanitschi, sp. n.

[(Perak.) 
4. (3) Pubescence of abdomen otherwise coloured.

5. (10) Large species, 15 or $16 \mathrm{~mm}$.

6. (7) Thoracic pubescence dark, pubescence on median segment canary-yellow. .

7. (6) Thoracic pubescence fulvous.

8. (9) Scopa on hind tibim and tarsi black

9. (8) Scopa on hind tibio and tarsi black and fulrous $\ldots \ldots \ldots \ldots \ldots \ldots$

10. (5) Medium to small species, 8-12 $\mathrm{mm}$.

11. (12) Male, $8 \mathrm{~mm} . \quad \ldots \ldots \ldots \ldots \ldots \ldots$.

12. (11) Females.

13. (14) Thoracic pubescence pale, abdomen black, with pale apical fasciø ....

14. (13) Thoracic pubescence fulvous.

15. (16) Clypeus b'ack; pale yellow apically; antennæ black ...............

16. (15) Clypeus yellow, with two subquadrate yellow marks, antenno black, scape and joint 3 ferruginous ......... rhodesia, sp. n.

[(Assam.)

psetudobomboides, sp. $\mathrm{n}$.

pseudoconcinna,

fulvohirta, sp. $\mathrm{n}$.

(Singapore.)

torridella, sp. $\mathrm{n}$.

pygmae, sp. n.

[(Africa.)

oldi, sp. n. (Africa.)

[(Africa.)

Anthophora nubica, Lep., val. uganda, var. nov.

ㅇ. Nigra ; capite, thorace (metathorace excepto), pleuris griseovillosis, pilis intermixtis nigris; metathorace dense nigrovilloso; abdomine nigro, tergite 4 omnino, 5 lateribus albohirsutis; tergite 5 fimbria, mediana, fusca; mandibulis basi et apice testaceis, clypeo linea mediana longitudinali, apice extremo maculaque labro basi pallide flavis; pedibus intermediis ac posticis nigro-hirtis.

Long. $15 \mathrm{~mm}$.

ๆ. Differs from both typical $A$. nubica, Lep., and var. somalica, Magr., in having the pale pubescence on head and thorax much less conspicuous. 'This pubescence has an almost bluish appearance, due apparently to the admixture of griseous and black hairs. In having tergite 4 covered with pale pubescence and the metathorax clothed with dense black pilosity, this form combines the characters of the typical form and var. somalica; the pale markings on the clypeus are much more reduced than in the typical form.

Length $15 \mathrm{~mm}$.

6 우.

Uganda Protectorate : Buddu, west shores of Victoria Nyanza, 3700 ft., ix. 1911 (type) ; Budongo Forest, Unyoro, 3400 ft., xii. 1911 ; Buamba Forest, Semliki Valley, 2300-2800 ft. (S. A. Neave). 


\section{Anthophora pseudoconcinna, sp. $\mathrm{n}$.}

. Nigra, fulvo-pilosa, pedibus plerumque nigro-pilosis; similis $A$. coneinno, sed major, pedibus intermediis posticisque (tibiis iii. supra exceptis) nigro-hirtis ; antennis nigris obscureve ferrugineis infra; clypeo (duabus maculis subquadratis nigris exceptis) labroque flavis, mandibulis basi flavis, apice ferrugineis; area postoculari, pleuris, abdomine lateribus tibiisque iii. supra albopilosis; ano brunneo; alis hjalinis.

Long. $16 \mathrm{~mm}$.

q. Black; head, thorax, and abdomen almost wholly clothed with fulvous pubescence, that on thorax mixed with black hairs; the space behind the eyes, the jowls, clypeus, labrum, pleura, sternum, abdominal segments 2-5 laterally, anterior legs, and posterior tibix above clothed with white pubescence.

Anal fascia chocolate-brown. Mandibles at base, labrum, and a L-shaped mark on clypeus pale lemon-yellow. Mandibles apically and tegulæ ferruginous. Wings hyaline.

Length $10 \mathrm{~mm}$.

Numerous of $q, 3$ os $\delta$.

$\delta$. Similar to the female, differing only sexually, scape yellow beneath.

Souti Africa : Sterkfontein, 'Transvaal (H. P. Thomasset) (type $q$ ). British LAS'T AfriCA: Upper Kuia Valley, S. Kavirondo (4200 feet) ; Makindu, Mtito Andei, iii-iv. 1911 (S. A. Nenve). Uganda : Entebbe (C.C. Gowdey), Western Ankole ( $4500-5000 \mathrm{ft}$.$) , Banks of Nile, near$ Kakindu (S. A. Neave). British Central Africa : West Nyasa (Lr.J.E.S.Old). A Brssinia : Higo Samula and Busika $(R . J$. Stordy).

'This appears to be a species of wide distribution, but of very constant colouring. It has the general facies of A. concinna, Klug (=vestita, Sm.), and $A$. capensis, Fr., but may be separated at once from these two species in having the intermediate and posterior legs with densely black pubescence, relieved only by a white fringe on the posterior tibia ; it also resembles $A$. africana, Fr., but that species has both pleura and posterior legs with black pubescence.

\section{Anthophora pygmaxa, sp. n.}

9. Nigra; clypeo labroque (maculis inconspicuis exceptis) mandibulis basi pallide luteis; tegulis ferrugineis; capite thoraceque 
ochraceo-pubescentibus, mesonoto pilis nigris intermixtis, abdomine fasciis apicalibus pallidis, fimbria anali brunnea; segmentis subtus albido ciliatis, pedibus plerumque griseo-hirtis, tibiis metatarsisque posticis supra albo-, subtus nigro-villosis; alis hyalinis.

Long. $8 \frac{1}{2} \mathrm{~mm}$.

9. Black; clypeus (except for two small black marks near base), an elongate spot above it, labrum and mandibles basally yellow; mandibles at apex and tegulæ ferruginous; head and thorax covered with pale pubescence, that on thorax tinged with ochraceous, and on scutellum and metanotum mixed with black hairs; pubescence behind the eyes, on the jowls and pleura, white; tergites 1-3 with apical fascize of pale ochraceous pubescence, tergite 4 with a griseous fascia, anal fimbria chocolate-brown. Front legs with short pale pubescence, the tarsi with black hairs, middle and posterior legs with silvery pubescence, pubescence below black. Wings hyaline.

Length $8 \frac{1}{2} \mathrm{~mm}$.

d. Similar to the female, but with the usual sexual differences, viz., scape beneath, cheeks, clypeus, labrum, and mandibles at base ivory-white.

A long series of both sexes.

Norte Rhodesia: Lower Luangwa River, ix. 1910 (type); Mid-Luangwa Valley; Luwumbu Valley, Upper Luangwa, 2500-3500 ft.; Alamadzi River, vii.-ix. 1910 (S. A. Neave); 80 miles west of Kamba Gorge, 1900 (O. Silverlock).

This small and sombrely coloured species is strongly reminiscent of the Palæarctic A. bimaculata, Panz.

\section{Anthophora torridella, sp. n.}

o. Nigra; scapo antice, genis, clypeo, labro, mandibularum basi albis; flagello tegulisque ferrugineis ; capite, thorace, abdominisque segmentis 1-6 fasciis apicalibus fulvo-hirtis; pedibus extus ochraceo- intus nigro-pubescentibus; alis hyalinis. Long. $8 \mathrm{~mm}$.

б. Black; scape beneath, cheeks, clypeus, labrum, and mandibles at base ivory-white ; flagellum and tegulæ ferruginous; head and thorax covered with fulvous pubescence, paler on pleura and sternum ; tergites 1-6 with fulvous apical fasciæ of pubescence, tergite 1 with long fulvous hair basally as well as apical fascix; pygidium acute, striate, fringed with fulvous hair. Legs uniformly clothed on outside with pale ochraceous pubescence, on the inside with 
black pubescence. Joint 3 of antennæ short, hardly so long as $4+5$. Wings clear hyaline,

Length $8 \mathrm{~mm}$.

$15 \delta 8$.

Northern Rhodesia : Mid-Luangwa Valley, viii. 1910 (S. A. Neave).

Strongly resembles $A$. pygmcea, but has fulvous pubescence.

\section{Anthophora oldi, sp. n.}

ㅇ. Nigra ; clypeo apice, labro mandibulisque basi luteis; tegulis ferrugineis ; capite, thorace abdominisque segmentis 1,2 fulvo-, segmentis 3,4 et 5 (laterale) pedibusque plerumque griseohirtis ; segmentis 1-4 apice fasciatis ; alis hyalinis.

Long. $12 \mathrm{~mm}$.

Black; the apical margin of elypeus, labrum, and mandibles at base yellow; head (except beneath) and thorax covered with a fulvous pubescence, paler on the face, denser and darker on the thorax (on the mesonotum some black hairs are intermixed), tergites 1 and 2 with a short, sparse, fulvous clothing ; the area behind the eyes, the head beneath, mesopleura below densely, tergites 3,4 wholly, and 5 on the sides sparsely clothed with griseous pubescence; all the tergites have distinct apical fasciæ, that on tergite 1 fulvous, the rest griseous, anal timbria dark chocolate-brown.

Front legs pale with long hair at base of femora, middle and posterior legs with a mixture of dense silvery-brown hair on tibiæ and tarsi. Tegulæ ferruginous, Wings byaline.

Length $12 \mathrm{~mm}$.

9 ㅇ․

Nyasaland : Blantyre (Dr.J.E.S.Old) (type); Valley of Bukuru River, 3000 ft., vi. 1910 (S. A. Neave). Congo Free State: Katanga, Kambove, 4-5000 ft. (S. A. Neave). N. Rhodesia : Broken Hill, ii. 1912 (F. V. Bruce-Miller).

\section{Anthophora rhodesice, sp. n.}

․ A. oldi affinis, sed clypeo flavo, duabus maculis subquadratis basi, nigris ; tibiis iii. metatarsisque nigro-hirtis ; capite, thorace supra, abdominis segmentis 1-3 fulvo-, 4-5 griseo-hirtis; ano fusco; labro areaque postoculari infra albo-, mesopleuris pallide flavo-hirtis; pedibus 1 pallide-, 2 et 3 nigro-hirtis; antennis plernmque nigris, scapo, art. $3^{\text {tio }}$ tegulisque ferrugineis; alis hyalinis.

Long. $12 \mathrm{~mm}$.

Ann. \& Mag. N. Hist. Ser, 8, Vol, xiii. 
Black, face covered with golden brown and whole of thorax above with a dense orange-red pubescence, paler on pleura. Tergites 1 and 2 with short, dense, orange-red pubescence, tergite 3 with grey and reddish hair intermixed, tergites 4 and 5 densely covered with griseous pubescence, anal fimbria dark chocolate-brown; sternites clothed with a dark ferruginous pubescence, all the segments with an interrupted apical fascia of pale pubescence. Area behind the eyes and the cheeks covered with dense long white hair. Mandibles at base and labrum pale yellow, with a sparse covering of white pubescence; clypeus mostly pale yellow, with two subquadrate marks at base black. Front legs corered with pale pubescence, that on femora long and griseous, on tibiæ and tarsi pale golden; middle and posterior legs mostly covered with dense chocolate-brown hairs, the intermediate tibiæ and posterior knees golden brown. Antennæ for the most part black; scape, joint 3 , and tegula ferruginous. Wings hyaline.

A long series of $q q$.

Length $12 \mathrm{~mm}$.

N. RHODESIA: Upper Luangwa River, vii.-viii. 1910 (type), Niamadzi River, near Nawalia (2000 ft.), and Chiwera, ix. 1911; Mid-Luangwa Valley (S. A. Neave); Ulunga ( $F, V$. Bruce Miller).

This handsome species comes very near $A$. oldi, but the thoracic pubescence is a much richer orange-red. Other differences are as follows :-

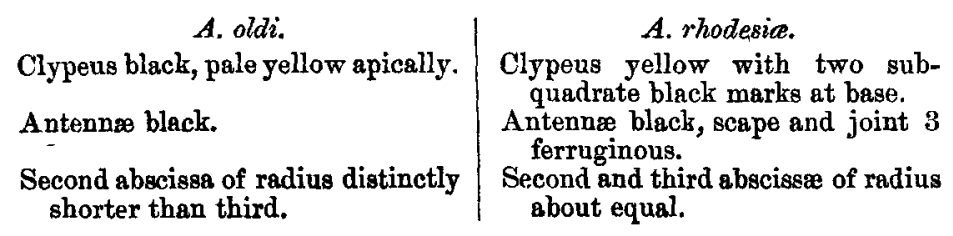
Anthophora (Habropoda) rovlandi, sp. n.

․ Nigra; eapite, thorace abdomineque pallide fulro-pilosis; eapite prothoraceque pilis nigris intermixtis; tergite secundo nigro-fasciato; antennis labro clypeoque nigris, mandibulis subferrugineis ; pedibus fulvo-pilosis ; alis hyalinis.

Long. $15 \mathrm{~mm}$.

Black ; the head, thorax, and abdomen clcthed with a pale fulvous pubescence, that on the head and prothorax intermixed with black hairs; clypeus sparsely clothed with dark 
hair; pubescence on abdomen somewhat more reddish towards apex, tergites 2 with a transverse fascia of dark hair. Antennæ, clypeus, and labrum black, the labrum with a covering of golden-brown hairs; mandibles faintly ferruginous. Legs ferruginous, the pubescence golden brown.

Clypeus and mandibles at base finely and evenly punctured, vertex subnitidulous, almost impunctate. Wings hyaline.

Length $15 \mathrm{~mm}$.

$\delta$. Similar to $q$, differing only in having the clypeus totally pale yellow. The scape is black beneath, not yellow, as is so prevalent in males of this genus.

4 o $q, 4$ o d .

AsSaM: Shillong, viii. 1903 (R. E. Turner).

This species, which I have pleasure in naming after its captor, is apparently near to $A$, (Habrop da) khasiana, Cam. (=fulvipes, (Yam,, Ann. \& Mag. Nat, Hist, (7) xiii. p, 211, 1904), but may be distinguished from it by the entirely black clypeus, without any keel, Cameron describes his species as having the "face tuberculate in the middle"; there is no such character in $A$, rowlandi,

\section{Anthophora fulvohirta, sp. n.}

9. Nigra; capite, thorace, pleuris, terg. $1-4$, pedibus plerumque fulvo-hirtis ; area postoculari pilis longis et albidis, vertice pilis nigris testaceisque intermixtis; terg. 5 nigro, fascia apicali metatarsisque iii. (basi excepto) nigro-pilosis; antennis nigris supra, scapo albido infra, art. 9-12 ferrugineis infra; tegulis ferrugineis; mandibulis (apice excepto), genis clypeoque apico linea longitudinali favidis; alis subhyalinis, venis nigris. Long. $15 \mathrm{~mm}$,

q. Black; head, thorax, pleura, tergites $1-4$, and legs for the most part clothed with fulvo-ferruginous hair, that on the vertex intermixed with long black and testaceous hairs and on the jowls with long and white hair ; tergite 5 black, with an apical fascia of black hair, metatarsus iii, (except basally) black-haired; tegula ferruginous; mandibles (the apex excepted), cheeks, the clypeus apically, and a narrow longitudinal line at right angles to the apical band yellowish, Wings subbyaline, the nervures black.

Clypeus and labrum rather coarsely and evenly punctured, thorax and abdomen finely; joint 3 of antenna equal in length to joints 4,5 , and 6 .

length $15 \mathrm{~mm}$,

J. More slender, otherwise differing only sexually. 
3 \% क, 3 के ठे.

Malay Peninsula: Singapore, $2 q q, 2$ o $\delta$ (type $q$ ), and Kukub, S.W. Johore (H. N. Ridley, H.R.S.), 1 o. Bolneo; Sandakan, 28. vii. 1893, 1 q.

\section{Anthophora hanitschi, sp. n.}

․ Nigra ; capite thoraceque viridi-pubescentibus, pilis nigris intermixtis, abdomine supra splendide viridi-pubescenti, pilis sparsis et fulvis intermixtis; terg. 5 fascia apicali fulvo-pilosa; pedibus plerumque nigro-hirtis, sed coxis trochanteribusque albo-pilosis, tarsis anticis tibiisque posticis supra fulvo-pilosis; area postorbitali pleurisque pallide pilosis; mandibulis basi duabus maculis, labro, elypeo apice lineaque longitudinali flavis; alis subhyalinis.

Long. $16 \mathrm{~mm}$.

\$. Black; head and thorax clothed with green pubescence, with black hairs intermixed, abdomen above clothed with rich emerald-green pubescence, with fulvous hairs somewhat sparsely intermingled; sternites ferruginous, with sparse apical fasciæ of fulvo-ferruginous hair; tergite 5 with an apical fascia of fulvo-ferruginous hair. Legs for the most part black-haired, but coxæ and trochanters with white pubescence, anterior tarsi and posterior tibiæ above fulvoushaired; the area behind the eyes, the jowls, and pleura clothed with whitish pubescence. Mandibles basally and labrum with two yellow spots, clypeus at apex and a narrow longitudinal line at right angles to apical line yellow. Wing: subhyaline. Mandibles and hypopygium impunctate, labrum and cly peus (except the nitidulous yellow longitudinal line) distinctly and evenly punctured; vertex, thorax, and abdon:en covered with even fine punctures; joint 3 of antenuæ equal to joints $4,5,6$.

Length $16 \mathrm{~mm}$.

PeIAK : Maxwell's Hill, 20th Aug., 1908 (Dr. R. Hanitsch). 1 ㅇ.

This handsome species is dedicated to Dr. Hanitsch, Curator of the Singapore Museum, by whom it was collected and presented. The only other Eastern representative of the genus with similar green pubescence is $A$. ceruginosa, Sm., from Australia, which may be immediately distinguished by its smaller size and the absence of fulvous pubescence on the hind tibiæ. Viewed from above the abdominal pubescence has a fulvous tinge; viewed from behind it is emerald-green. 
Anthophora pseudobomboides, sp. n.

오. Variegata; antennis, capite, thoraoe, terg. 1-3 nigris; nandibulis, terg, 4-6, sterno omnino, pedibusque ferrugineis; labro maculaque clypeali triangulari pallide flavis; vertice thoraceque nigro-, segmento mediano ochraceo-, genis pleurisque albo-hirtis ; terg. 1, 2 (lateribus exceptis), $4-6$ fulvo-, terg. 2 (lateribus) et 3 nigro-pubescentibus; pedibus nigro-hirtis, tibiis posticis apice penicillis ochraceis; alis pallide fuscis.

Long. $15 \mathrm{~mm}$.

ㅇ. A variegated species; the antennæ, head, thorax, and tergites 1-3 black; the mandibles, tergites 4-6, the sternum altogether, and the legs ferruginous. Pubescence as follows:- that on the vertex and thorax black, with a brownish tinge; on the median segment canary-yellow; on the jowls and pleura white; tergites 1,2 (with exception of sides), and 4-6 fulvous, tergite 2 laterally and 3 black; legs black-haired, the posterior tibiæ apically with ochraceous tufts. Wings faintly fuscous. Mandibles finely punctured, the whole insect otherwise almost impunetate; joint 3 of antennæe about equal to joints 4 and 5 .

Assam ( $W . F$. Badgley), 1 o .

A most distinct species, the canary-yellow pubescence on the median segment and the ferruginous and black abdomen giving a very Bombiform appearance to the species.

\section{Anthophora sicula, Smith, đ (nec o ).}

Two species are represented by the sexes of $A$. sicula, Smith. The name will stand for the male. The specimen labelled and described as $A$. sicula, o (the label, in Smith's handwriting, appears as "A. sicilia"), is $A$ '. acervorum, var. pennata, Lep. A $\$$ specimen from the Edward Saunders Collection, originally from the Smith Collection, bears Dr. Friese's determination " $A$. acervorum, var." 'I'he true $A$. sicula lacks the dilated tuft of hair on the intermediate tarsi and the long cilia on the other joints, so conspicuous in males of $A$. acervorum.

\section{Anthophora (Amegilla) villosula, Smith.}

Anthophora villosula, Smitb, Catal. Hymen. Brit. Mus. ii. p. 338 (1854). o.

Anthophora florea, Smith, Descr. New Spec. Hymen. p. 123 (1879). ㅇ. Anthophora pingshiangensis, Strand, Archiv für Naturg. Abt. A, Heft 3, pp. 105-107 (1913). ठ .

There can be no doubt that $A$. florea, Sm., is the female of 
his A. rillosula described some years previously. Both specimens come from the same locality (Shanghai). A good description of the female of $A$. villosula is given by Friese (' Die Bienen Furopas,' iii. p. 95). Male co-types of A.pingshiangensis, Strand, from Pingshiang, S. China, are typical A. villosula.

The following three African species, all rather similar in appearance and belonging to the $A$. quadrifasciata group, differ as below :-

Head and thorax black, with pale or fulvous pubescence ; abdomen with pale apical fascim of pubescence.

Tergites 4 and 5 covered with a sparse but distinct white pubescence ....

Tergites 4 and 5 covered with a sparse but distinct black ptibescence; posterior tibia with a pale scopa.

L Length $11 \mathrm{~mm} . . \ldots \ldots \ldots \ldots \ldots$

Clypeus coarsely punctured; pubescence on head and thorax abrve ochraceous mixed with black, that on pleura whitish; tergite 1 with apical fascia pale fulvous; posterior tibire with a whitish scopa. Length

2.

15 mm.........................

2. cence on head and thorax rich orange= red, that on pleura paler; tergites 1-3 with apical fascico pale fulvous, posterior tibio with bright orangered scopa, and a tuft of white

pubescence at apex. Length $13 \mathrm{~mm}$. torrida, Sm. (Sierra Leone.)

A. torrida may be synonymous with $A$. calens, Lep., from Senegal. The type-specimen agrees very well with Lepeletier's excellent description of $A$. calens. Specimens labelled as "A. calens" in Smith's collection are certainly identical with his own $A$. torrida.

\section{Anthophora bipartita, Smith.}

Anthophora bipartita, Sm., var. favicollis, Gerst.

Anthophora bipartita, Sm., var. nigroclypeata, Fr.

It seems highly probable that this species and A.flavicollis, Gerst., are varieties of the same species; and since Smith's species has priority of publication, A. flavicollis must be considered the variety. The difference is exactly similar to that existing between $A$, armata, Fr., and the var. clitelli- 
gera, Fr., except that in this species it is the typical form which has the thornx unicolorous, whereas in A.bipartita the var. flavicollis is so marked. Again, it would seem that A. nigroclypeata, Friese, is no more than another variety, in which the clypeus and labrum are black, with the cephalic pubescence of the same colour. Friese ("Die Bienen Afrikas,' p. 270) notices the near relationship, but had only seen specimens of the two forms from East and West Africa respectively. The two forms, however, overlap in Ugauda, the meeting-place of the East and West African fauna. Further, it would seem that the difference between nigroclypeata and flavicollis applies only to the females, since a large series of males from the following localities show a remarkable similarity :-Sierra Leone (J.J. Simpson), S. Nigeria (W. C.W. Eakin), N. Nigeria (J.W. Scott Macfie), Gold Coast (H. T'. Palmer), Uganda Protectorate and Brit. East.Africa (S.A. Neave), Nyasaland (J.E.S.Old), and the Transvaal (H.P. Thomasset).

\section{Anthophora acraensis, F.}

Without having seen the type it is very difficult to determine satisfactorily the typical form of this species. There is a large series in the British Museum, from numerous localities in both tropical and subtropical Africa, apparently referable to A.acraensis. The specimen described by Fabricius (Ent. Syst. ii. p. 329) was a male. Dours is certainly correct (Monogr. Icon., Anthophora, p. 84, 1869) in interpreting the "caput nigricans" referred to by Fabricius as meaning. that the hairs of the face and head beneath ( $i . e$. behind the eyes) were white, those on the vertex intermingled with black.

"Ano albo," also from the Fabrician diagnosis, is very vague. According to Dours $(l . c$.) segments 6 and 7 are covered with white pubescence mixed with ferruginous; Friese ('Die Bienen Afrikas,' p. 269) considers segment 5 to be clothed with white hair. Probably this is variable, since in var. albocaudata, Dours, segment 4 is also white.

Anthophora advena, Smith (type in B. M.), has been considered cospecific with $A$. acraensis, F.; but "thorax ... subtus niger" (Fabricius, l. c.) does not agree with Smith's species, in which the sternum is griseous. The fourth and following segments of the abdomen are clothed with white pubescence, as in var. albocaudata, Dours, of which it may be the male. 
Anthophora cincta, F.

The locality (Malabar) given for this species by Fabricius in lis original description (Spec. Insect. i. p. 473, 1781) is certainly incorrect, for the species is without doubt Ethiopian, as noticed by Smith (Descr. New Spec. Hymen. p. 124, 1879). Fabricius himself was doubtful at a later date (Syst. Piez. p. 330, 1804), for he queries the locality.

The Anthophora cincta described by Dours (Monogr. Icon., Anthophora, $\mathrm{p}_{\mathrm{f}}$ 58) is an Australian species synonymous with A. cingulata, F., q. v.

Friese did not know $A$, cincta, F., from Africa, but Vachal records it from several West-A frican localities.

In the British Museum there is a typical series from the Uganda Protectorate: west shore of Victoria Nyanza, Buddu (3700 ft.), Sept. 1911 (S. A. Neave); Entebbe, May 1912 (C. C. Gowdey). Sierra Leone: Free Town, Sept. 1899 (E. E. Austen). Northern Nigeria: Dec. 1912 (J. J. Simpson).

The following description is taken from the type in the Banks Collection at the British Museum :-

i. Black; mandibles (except exireme apex), labı um, and a thin $\perp$-sbaped mak on clypeus pale yellow. Head, thorax, and pleura more or less densely clothed with green pubescence, intermixed with a few black hairs; pubescence behind the eyes below whitish. All the tergites with apical metallic-green fasciæ, those on tergites 3-5 widening medially. Legs: anterior pair covered with green pubescence, intermediate tibiæ and tarsi green above, black beneath; posterior legs black, the tibiæ ferruginous above. Antennæ black, fligellum ferruginous beneath.

\section{Anthophora vivida, Smith.}

Friese ('Die Bienen Afrikas,' p. 264) wrongly gives the first abdominal segment as having a blue fascia; the first segment is entirely black.

\section{Anthophora modesta, Smith.}

Dalla Torre (Catal. Hymen. x. p. 277) gives this species as American. The type, which is in the British Museum, is from St. Vincent, Cape Verde Islands. There are also specimens with no more explicit data than "West Africa."

It is a most striking insect ; black, with an apical fascia of white pubescence on the first tergite, and has the inter- 
mediate and posterior legs richly clothed with dense fulvousred scopa.

'lotal length $15 \mathrm{~mm}$.; length of fore wing $11 \mathrm{~mm}$.

Anthophora albigena, Lep., subsp. fallax, Sm.

Anthophora fallax, Sm. New Spec. Hymen. Brit. Mus. p. 120 (1879). ¿' o. (Sierra Leone.)

Anthophora lucknoviensis, Rad. Wiadom. z nauk Przyrodz. Warszowa, ii. p. 76 (1882). ơ. (Lueknow.)

Smith's A. fallax is evidently a subspecies of the widely spread $A$. albigena, Lep., and specimens from $\mathrm{N}$. Bengal, lBombay, and Ceylon stand in the British Museum series, placed there by Smith himself.

A. alhigina, subsp. quadrata, (kll., recently described from Nasik, Bombay Presidency (Comber Coll.), is also this subspecies.

Anthophora albigena, Lep., var. pyramidalis, W. F. Kirby.

The Podalirius pyramidalis described by Kirby from Socotra (Bull. Soc. Liverp. Mus. iii. p. 24, 1900) was considered by Kohl to be co-specific with A. albigena, Lep., a widely distributed species in the South Palæarctic region; but at the same time he recognizes that it may be considered a variety, in which case Kirby's name would stand ("Hymenopteren Südarabiens,' p. 4, 1905).

A comparison between cu-types of Kirby's insect and specimens of typical $A$. albigena from Algeria shows the following differences :-

A. alligena, Lep.- Scape beneath bare; cheeks white; hair on posterior tibiæ white.

A. albigena, Lep., var. pyramidalis, W. F. Kirby.-S'cape beneath clothed with short, dense, white pubescence; cheeks llack; hair on posterior tibia fulvous.

\section{Anthophora himaluyensis, Rad.}

Anthophora himalayensis, Rad. Wiadom, z nauk. Przyrodz. Warszowa, ii. p. 75 (1882).

Anthophora proserpina, Grib. Buil. Soc. Ent. Ital. xxv. p. 286 (1893).

I have compared a specimen of $A$. proserpina, taken by myself at the type-locality (Malacca) in 1908; it agrees perfectly with Gribodo's description. 'The species is certainly synonymous with $A$. himalayensis, Rad., of which the British Museum possesses a good series from Middle 'Tenas. serim and Sikkim (Bingham Coll.). 
Anthophora himalayensis, Rad., var. pahangensis, var. nov.

․ A. himalayensi typico similis, sed terg. 1-3 faseiis apicalibus rufescente-pilosis.

o. Sinilar to the typical form, but tergites 1-3 with apical fascia of rufous pubescence, that on tergite 3 widely broken medially.

Pahang: Gunong Tahan (2500-3500 ft.), v.-vii. 1905 (Herbert C. Robinson), 1 o (type); there is also a female from Mt. Ophir, Johore, 12th Aug. 1905 (Dr. R. Hanitsch), in bad condition, but probably belonging to this variety.

\section{Anthophora cingulata, $\mathrm{F}$.}

Megilla cingulata, F., Syst. Piez. p. 332. no. 18 (1804).

Anthophora cincta, Dours (nec Fabr.), Mon. Icon. Anthophora, p. 58 (1869). $q$.

Anthophora emendata, Smith, New Spec. Hymen. Brit. Mus. p. 123 (1879). ơ (nec q).

Anthophora emendata, Smith, var. gilberti, Ckll. Ann. \& Mag. Nat. Hist. (7) xvi. p. 396 (1905). ․

The type of this species is in the Banks Collection in the British Museum. Smith incorrectly gives his type of $A$. emendata as a $q$, which accounts for Cockerell's description of a new variety. The type of $A$. emendata is a $\sigma^{*}$, and the var. gilberti, Ckll., is certainly the female of the same species.

The two specimens from Clare, South Australia (Ann. \& Mag. Nat. Hist. (7) xvi. p. 397, 1905), are erroneously recorded as this species.

\section{Emphoropsis carinifrons, Cam.}

'This species, from Hacienda Guachala, Ecuador ( $E d$. Whymper), was described as Habropoda. Cockerell has already (Canad. Ent. xxxvi. p. 302) transferred Smith's Mexican species (also described as Habropoda) to Emphoropsis. $\boldsymbol{E}$. bombiformis, Sm. (1879), is omitted from Dalla Torre's catalogues. 